\title{
Elemental composition of human hair in different territories of the Crimean peninsula
}

\author{
Elena Evstafeva $^{1 *}$, Nataliya Baranovskaya $^{2}$, Anna Bogdanova $^{1}$, Osman Ablialimov $^{1}$, Anna \\ Macarova $^{3}$, Irina Evstafeva ${ }^{1}$, and Elena Yaseneva ${ }^{4}$ \\ ${ }^{1}$ V.I. Vernadsky Crimean Federal University, 295006 Lenin Avenue 5/7, Simferopol, Russian \\ Federation \\ ${ }^{2}$ National Research Tomsk Polytechnic University, 634050 Lenin Avenue 30, Tomsk, Russian \\ Federation \\ ${ }^{3}$ Mendeleyev University of Chemical Technology of Russia, 125047 Miusskaya sqr. 9, Moscow, \\ Russian Federation \\ ${ }^{4}$ The Branch of the Moscow State University (in Sevastopol), 299000, Heroes of Sevastopol Street 7, \\ Sevastopol, Russian Federation
}

\begin{abstract}
The chemical homeostasis of humans has changed due to global and local anthropogenic impacts on biogeochemical cycles. Their degree is mediated by natural geochemical character of local environments. The elemental composition of human hair and quantitative relation between elements is summary characteristic of biogeochemical environmental conditions. To determine the biogeochemical situation 78 inhabitants from different geographic regions across the Crimean peninsula, cities and rural areas were investigated through the analysis of 28 elements by neutron activation analysis and determination of mercury by atomic absorption spectroscopy. High variety of elemental composition in inhabitants' hair on different types of territories in the Crimean peninsula was revealed. Comparison with different territories of Russian Federation and Belarus shows both common and specific features. On most part of Russian and the Crimean territories a deficiency of essential elements $(\mathrm{Zn}, \mathrm{Cu})$ in human hair is characteristic. At the same time there are significant differences in content of some essential elements $(\mathrm{Ca}, \mathrm{Fe})$ and other ones (Th, $\mathrm{Ce}, \mathrm{Au}, \mathrm{U}$, $\mathrm{Ag}, \mathrm{Cs})$ even in the limited Crimean territory. It requires further investigation of factors, which determine the revealed variability.
\end{abstract}

\section{Introduction}

Investigation of living organisms' chemical variability is a fundamental objective for science. It acquires special relevance in the conditions of anthropogenic transformation of the biosphere because the chemical homeostasis of humans changes due to global and local biogeochemical cycle's alteration. The transformation degree depends on natural geochemical characteristics of landscape that mediates the final intake of chemical contaminants into the human body. This is particularly important in regions such as the

\footnotetext{
*Corresponding author: e.evstafeva@mail.ru
} 
Crimean peninsula, which has a wide diversity in soil composition: 8 types of soil-forming rocks, especially in the Crimean Mountains [1]; 22 soil types, which are located in 7 soil and climate zones [2]. At the same time expected variety of biogeochemical characteristics, which reflected in human hair composition [3], in the Crimea was not described. Only in two biogeochemical regions large-scale differentiation is known: mountain and foreststeppe and steppe chernozems [4].

To determine the biogeochemical variety of different types of territories in the Crimean peninsula the elemental content of chemical elements in inhabitants' hair was investigated.

\section{Materials and methods}

Sufficiently wide range of chemical elements is required to determine a chemical variability. For this reason the determination of 29 elements in hair of inhabitants from northern, western, northwestern, southwestern, central, eastern and southern regions (Fig.1) was carried out. According to E. Underwood (1962) this list includes: essential and conditionally essential ( $\mathrm{Ca}, \mathrm{Cr}, \mathrm{Fe}, \mathrm{Zn}, \mathrm{Na}, \mathrm{Au}, \mathrm{Ag}, \mathrm{Co}$ ) elements; toxic and conditionally toxic ones (Br, As, Rb, Sr, Cs, Eu, La, Yb, Th, U, Ba, Nd, Hg, Sb, Ta, Tb, Sm, Hf, Ce), and elements without established physiological role (Lu, Sc). Some of them are considered [5] as biogenic ( $\mathrm{Na}, \mathrm{Ca}, \mathrm{Fe}, \mathrm{Zn}, \mathrm{Co}, \mathrm{As}, \mathrm{Au})$ and abiogenic (Rb, Sr, Cs, Ba, Hg). In general, 33 males and 45 females who were 17-19 years old, healthy and lived in the studying areas during all their life were examined. Among them 44 persons lived in cities and 34 persons lived in rural areas. The hair samples were taken from the occipital basal areas close to the hair root $(2-3 \mathrm{~mm})$ in amount at least 5 grams [3]. Then, hair samples were rinsed twice with distilled water and acetone alternately to delete external pollutants and dried in an oven at $30{ }^{\circ} \mathrm{C}$ for 20 hours [3]. After that, each sample was weighted (100 mg) and placed in aluminum foil packets. Sample preparation and the determination of elements were carried out in the International Innovative Center of Science and Education "Uranium geology" in National Research Tomsk Polytechnic University. To determine a content of 28 elements in human hair the modern highly-sensitive nuclear-physical method of neutron activation analysis with thermal neutrons irradiation at Tomsk's research nuclear reactor was used. Mercury content was determined by atomic absorption spectrometry using Zeeman's correction nonselective absorbance analyzer «PA-915M», pyrolitic console «PIRO-915+» and software package RA915P.

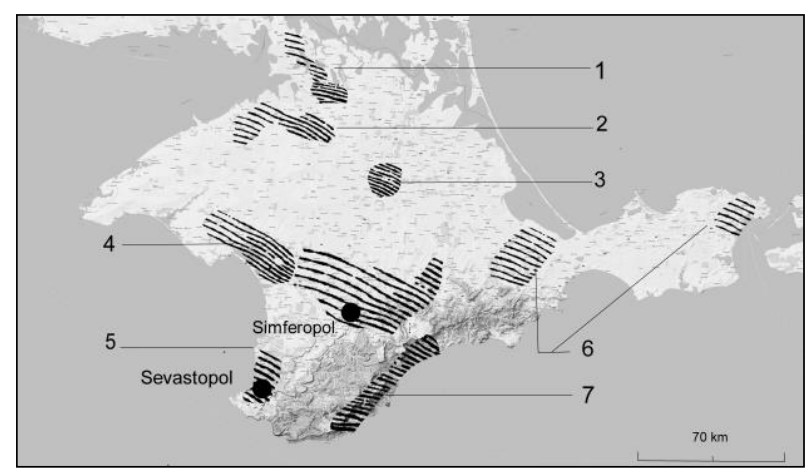

Fig. 1. The regions of residence of tested inhabitants on the territory of Crimea peninsula: 1-northern, 2- northwestern, 3- central, 4- western, 5- southwestern, 6- eastern, 7- southern.

For comparative assessment the element's content in human hair in different territories of the Crimean peninsula concentration coefficient $\left(\mathrm{C}_{\mathrm{c}}\right)$ was calculated, as the relation $\left(\mathrm{C}_{\mathrm{c}}=\mathrm{C}_{\mathrm{i}} / \mathrm{C}_{\mathrm{a}}\right)$ of found element content in humans on definite territory $\left(\mathrm{C}_{\mathrm{i}}\right)$ to "average 
Crimean" value of element content for all tested inhabitants $\left(C_{a}\right)[6]$. The calculation results of $\mathrm{C}_{\mathrm{c}}$ have been presented in a form of geochemical associative rows of elements in descending order. Also, the total indicator $\left(\mathrm{Z}_{\mathrm{c} i}\right)$ of content of whole studied row of elements $\left(\mathrm{Z}_{\mathrm{c} i}=\sum \mathrm{C}_{\mathrm{c}}\right)$ for each tested group was determined. Abnormality coefficient accumulation $\left(\mathrm{C}_{\mathrm{aa}}\right)$ was calculated as sum of concentration coefficients for elements with content above "average Crimean" $\left(\mathrm{C}_{\mathrm{aa}}=\sum \mathrm{C}_{\mathrm{c} \geq 1}\right)$.

\section{Results}

The distribution pattern of analytical results according to $\mathrm{C}_{\mathrm{c}}$ values in a form of geochemical associative rows, which represent the ratio of the average elements' content in the residents' hair of each region to the average elements' content in the entire studied group, are listed below for different regions of the Crimean peninsula. Distinct differences are apparent between these geographic regions. For example, geochemical associative rows of elements in hair of healthy inhabitants are as follows:

1. The northern region:

$\mathrm{Nd}=\mathrm{Ag}_{2,2}>\mathrm{U}_{2,0}>\mathrm{Eu}_{1,8}>\mathrm{Sc}=\mathrm{Sb}_{1,7}>\mathrm{Co}=\mathrm{Yb}_{1,2}>\mathrm{Ta}=\mathrm{Rb}_{1,1}>\mathrm{Zn}=\mathrm{Ce}=\mathrm{Sr}_{1,0}>\mathrm{Sm}=\mathrm{Ba}=\mathrm{Br}=\mathrm{Hg}_{0,9}>\mathrm{Cs}_{0,8}$ $>\mathrm{Tb}=\mathrm{Th}_{0,7}>\mathrm{Cr}=\mathrm{As}=\mathrm{Na}_{0,6}>\mathrm{La}=\mathrm{Ca}_{0,5}>\mathrm{Lu}_{0,4}>\mathrm{Hf}_{0,3}>\mathrm{Fe}=\mathrm{Au}_{0,1}$;

2. The northwestern region:

$\mathrm{Rb}_{1,5}>\mathrm{U}=\mathrm{Eu}_{1,3}>\mathrm{Sc}_{1,2}>\mathrm{Ta}=\mathrm{Sb}_{1,1}>\mathrm{Cr}=\mathrm{Ba}=\mathrm{Sr}=\mathrm{Zn}_{1,0}>\mathrm{Co}_{0,8}>\mathrm{Tb}=\mathrm{Sm}_{0,7}>\mathrm{Na}=\mathrm{Nd}=\mathrm{Hg}=\mathrm{Ce}=\mathrm{Th}=\mathrm{Yb}$ $=\mathrm{Ca}=\mathrm{Br}_{0,6}>\mathrm{La}_{0,5}>\mathrm{As}=\mathrm{Lu}_{0,4}>\mathrm{Hf}=\mathrm{Au}_{0,2}>\mathrm{Ag}=\mathrm{Cs}=\mathrm{Fe}_{0,1}$;

3. The western region:

$\mathrm{Eu}_{1,5}>\mathrm{Rb}=\mathrm{Sc}_{1,2}>\mathrm{Nd}=\mathrm{Au}=\mathrm{Zn}=\mathrm{Ba}_{1,1}>\mathrm{Ca}=\mathrm{Ta}=\mathrm{Sb}=\mathrm{Sr}_{1,0}>\mathrm{Co}=\mathrm{Ag}=\mathrm{Na}=\mathrm{Yb}_{0,9}>\mathrm{Tb}=\mathrm{Cr}=\mathrm{Sm}_{0,8}>\mathrm{Br}$ $=\mathrm{Lu}=\mathrm{Th}_{0,7}>\mathrm{As}=\mathrm{U}=\mathrm{Ce}_{0,6}>\mathrm{Hf}=\mathrm{La}_{0,5}>\mathrm{Hg}=\mathrm{Fe}_{0,4}>\mathrm{Cs}_{0,2}$;

4. The central region:

$\mathrm{Fe}_{1,5}>\mathrm{Hf}_{1,4}>\mathrm{Tb}_{1,3}>\mathrm{Yb}=\mathrm{Hg}=\mathrm{As}_{1,2}>\mathrm{Na}=\mathrm{La}=\mathrm{Cs}=\mathrm{Br}=\mathrm{Co}=\mathrm{Ag}_{1,1}>\mathrm{Ba}=\mathrm{Sb}=\mathrm{U}=\mathrm{Zn}=\mathrm{Ta}=\mathrm{Sr}=\mathrm{Ce}_{1,0}>$

$\mathrm{Eu}=\mathrm{Nd}=\mathrm{Lu}=\mathrm{Ca}=\mathrm{Rb}_{0,9}>\mathrm{Au}=\mathrm{Sc}=\mathrm{Sm}_{0,8}>\mathrm{Th}_{0,7}>\mathrm{Cr}_{0,4}$

5. The eastern region:

$\mathrm{Th}_{4,2}>\mathrm{Sm}_{2,3}>\mathrm{Ce}_{2,2}>\mathrm{La}_{1,7}>\mathrm{Sc}=\mathrm{Eu}_{1,6}>\mathrm{Cs}_{1,4}>=\mathrm{Cr}=\mathrm{Tb}_{1,2}>\mathrm{Na}=\mathrm{Sb}=\mathrm{Zn}=\mathrm{Rb}=\mathrm{As}_{1,1}>\mathrm{Sr}_{1,0}>\mathrm{Nd}=\mathrm{Ca}=$

$\mathrm{Ta}=\mathrm{Br}_{0,9}>\mathrm{Ba}=\mathrm{U}=\mathrm{Hf}_{0,8}>\mathrm{Co}=\mathrm{Yb}=\mathrm{Ag}_{0,7}>\mathrm{Hg}_{0,6}>\mathrm{Fe}=\mathrm{Lu}_{0,4}>\mathrm{Au}_{0,2}$;

6. The southern region:

$\mathrm{Au}_{2,6}>\mathrm{Ca}_{1,9}>\mathrm{Lu}_{1,5}>\mathrm{Rb}_{1,4}>\mathrm{Hg}_{1,1}>\mathrm{Ba}=\mathrm{Sr}=\mathrm{Eu}=\mathrm{Zn}_{1,0}>\mathrm{Ta}=\mathrm{Sc}_{0,9}>\mathrm{Sm}=\mathrm{Ce}=\mathrm{As}=\mathrm{Nd}_{0,8}>\mathrm{Cs}=\mathrm{Tb}_{0,7}>$ $\mathrm{Yb}=\mathrm{Na}=\mathrm{U}=\mathrm{Th}_{0,6}>\mathrm{La}=\mathrm{Sb}_{0,5}>\mathrm{Co}=\mathrm{Br}_{0,4}>\mathrm{Fe}=\mathrm{Ag}=\mathrm{Hf}_{0,3}>\mathrm{Cr}_{0,2}$;

7. The southwestern region

$\mathrm{Au}_{3,8}>\mathrm{Ag}_{2,8}>\mathrm{Br}_{2,4}>\mathrm{Cs}_{2,2}>\mathrm{Ca}_{1,9}>\mathrm{Hf}=\mathrm{Fe}_{1,6}>\mathrm{Co}_{1,5}>\mathrm{Lu}_{1,4}>\mathrm{Sb}=\mathrm{Yb}_{1,2}>\mathrm{Tb}=\mathrm{As}=\mathrm{Ta}_{1,1}>\mathrm{Na}=\mathrm{Th}=\mathrm{Sr}_{1,0}$ $>\mathrm{Ba}_{0,9}>\mathrm{Zn}=\mathrm{Sm}_{0,8}>\mathrm{La}=\mathrm{Sc}=\mathrm{Rb}_{0,7}>\mathrm{Nd}=\mathrm{Ce}_{0,6}>\mathrm{Hg}_{0,4}>\mathrm{Eu}_{0,3}>\mathrm{U}_{0,2}>\mathrm{Cr}_{0,1}$.

Geochemical rows of elements were calculated separately for inhabitants who live in cities and rural areas. Because more than a half of the people selected for the study $(n=40)$ live in Simferopol, a separate geochemical row was created for them:

$\mathrm{Fe}_{1,5}>\mathrm{Tb}_{1,4}>\mathrm{Ag}=\mathrm{Na}=\mathrm{Hf}=\mathrm{Hg}_{1,3}>\mathrm{As}=\mathrm{Br}=\mathrm{Co}_{1,2}>\mathrm{Yb}=\mathrm{La}=\mathrm{Sb}=\mathrm{Lu}=\mathrm{Au}_{1,1}>\mathrm{Ta}=\mathrm{Ba}=\mathrm{Cs}=\mathrm{Zn}=\mathrm{Sr}=\mathrm{Eu}$ $=\mathrm{Ca}_{1,0}>\mathrm{Ce}=\mathrm{Nd}=\mathrm{U}_{0,9}>\mathrm{Rb}=\mathrm{Cr}=\mathrm{Sc}_{0,8}>\mathrm{Sm}_{0,7}>\mathrm{Th}_{0,6}$.

By comparison, the geochemical row for inhabitants of other cities is as follows:

$\mathrm{Ag}_{1,5}>\mathrm{Tb}=\mathrm{Th}_{1,3}>\mathrm{Fe}=\mathrm{Hg}=\mathrm{La}=\mathrm{Hf}_{1,2}>\mathrm{Na}=\mathrm{Yb}=\mathrm{Au}=\mathrm{Br}=\mathrm{As}=\mathrm{Sb}=\mathrm{Co}=\mathrm{Ca}_{1,1}>\mathrm{Cs}=\mathrm{Ce}=\mathrm{Sm}=\mathrm{Ba}=\mathrm{Lu}$

$=\mathrm{Ta}=\mathrm{Sr}=\mathrm{Zn}=\mathrm{Eu}=\mathrm{Sc}_{1}>\mathrm{Rb}=\mathrm{Nd}_{0,9}>\mathrm{U}=\mathrm{Cr}_{0,8}$.

These urban results contrast with that for inhabitants of rural areas:

$\mathrm{Cr}=\mathrm{Eu}_{1,3}>\mathrm{U}_{1,2}>\mathrm{Rb}=\mathrm{Nd}=\mathrm{Sc}_{1,1}>\mathrm{Zn}=\mathrm{Sr}=\mathrm{Sb}=\mathrm{Ta}=\mathrm{Yb}=\mathrm{Ba} \mathrm{a}_{1}>\mathrm{Ce}=\mathrm{Co}=\mathrm{Cs}=\mathrm{Ca}=\mathrm{Br}=\mathrm{As}_{0,9}>\mathrm{Tb}=\mathrm{Na}=$ $\mathrm{Hf}=\mathrm{Sm}=\mathrm{Au}_{0,8}>\mathrm{La}=\mathrm{Hg}=\mathrm{Fe}=\mathrm{Th}_{0,7}>\mathrm{Lu}_{0,6}>\mathrm{Ag}_{0,4}$.

It is instructive to compare elemental composition among the inhabitants of the two largest Crimean cities, Simferopol and Sevastopol, which are located in different geographical areas and have different technogenic loads (Fig. 2). 


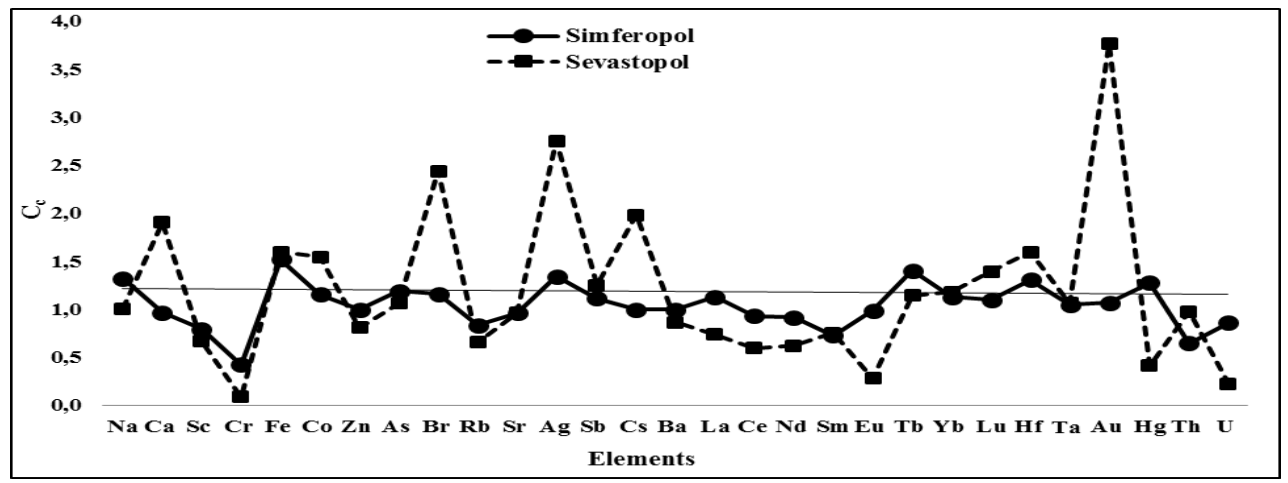

Fig. 2. Concentration coefficients $\left(\mathrm{C}_{\mathrm{c}}=\mathrm{C}_{\mathrm{i}} / \mathrm{C}_{\mathrm{a}}\right)$ of chemical elements in hair of Simferopol and Sevastopol inhabitants. Note: $\mathrm{Z}_{\mathrm{c} i}=\sum \mathrm{C}_{\mathrm{c}} ; \mathrm{C}_{\mathrm{aa}}=\sum \mathrm{C}_{\mathrm{c} \geq 1}$ (comments in the text).

It is worth noting that these parameters higher for inhabitants of cities compared to inhabitants of rural areas (Fig. 3).

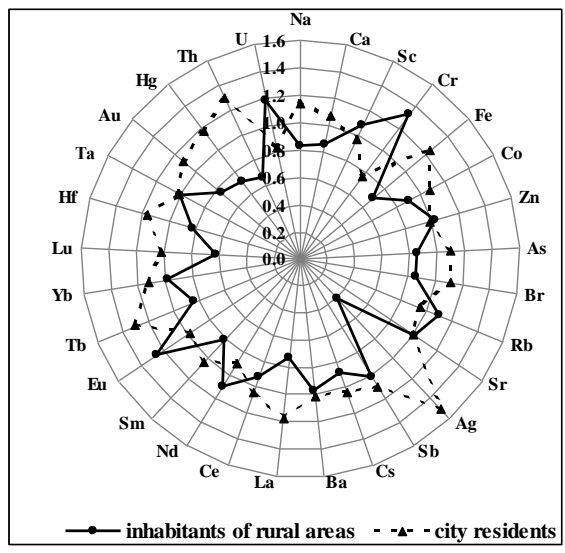

a

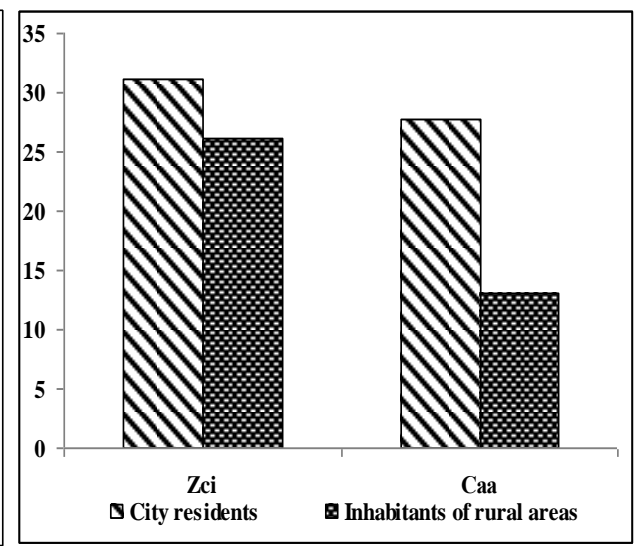

b

Fig. 3. Concentration coefficients $\left(\mathrm{C}_{\mathrm{c}}=\mathrm{C}_{\mathrm{i}} / \mathrm{C}_{\mathrm{a}}\right)(\mathrm{a})$, total indicators of content $\left(\mathrm{Z}_{\mathrm{c} i}=\sum \mathrm{C}_{\mathrm{c}}\right)$ and cumulative abnormality coefficient $\left(\mathrm{C}_{\mathrm{aa}}=\sum \mathrm{C}_{\mathrm{c} \geq 1}\right)$ (b) of elements in hair of inhabitants in cities and rural areas. Note: $\mathrm{C}_{\mathrm{c}}=\mathrm{C}_{\mathrm{i}} / \mathrm{C}_{\mathrm{a}} ; \mathrm{Z}_{\mathrm{ci}}=\sum \mathrm{C}_{\mathrm{c}} ; \mathrm{C}_{\mathrm{aa}}=\sum \mathrm{C}_{\mathrm{c} \geq 1}$ (comments in the text).

As it can be seen from the data above, $\mathrm{C}_{\mathrm{c}}$ was often higher than average Crimean level: from 10 to $220 \%$ for elements such as $\mathrm{Nd}, \mathrm{Ag}, \mathrm{U}, \mathrm{Eu}, \mathrm{Sc}, \mathrm{Sb}, \mathrm{Co}, \mathrm{Yb}$, Ta in the northern region; from 10 to $50 \%$ for $\mathrm{Rb}, \mathrm{U}, \mathrm{Eu}, \mathrm{Sc}, \mathrm{Ta}, \mathrm{Sb}$ in northwestern region, and $\mathrm{Eu}, \mathrm{Rb}, \mathrm{Sc}$, $\mathrm{Nd}, \mathrm{Au}, \mathrm{Zn}, \mathrm{Ba}$ in the western region; from 10 to $260 \%$ for $\mathrm{Au}, \mathrm{Ca}, \mathrm{Lu}, \mathrm{Rb}, \mathrm{Hg}$ in the southern region and from 10 to $380 \%$ for $\mathrm{Au}, \mathrm{Ag}, \mathrm{Br}, \mathrm{Cs}, \mathrm{Ca}, \mathrm{Hf}, \mathrm{Fe}, \mathrm{Co}, \mathrm{Lu}, \mathrm{Sb}, \mathrm{Yb}, \mathrm{Tb}$, As, Ta in the southwestern region; and from 10 to $420 \%$ for Th, Sm, Ce, La, Sc, Eu, Cs, Cr, $\mathrm{Tb}, \mathrm{Na}, \mathrm{Sb}, \mathrm{Zn}, \mathrm{Rb}, \mathrm{As}$ in the eastern region.

Analysis of cumulative indexes $Z_{c i}$ and $C_{a a}$ (Fig.4) also confirmed that their highest values were observed for inhabitants of the southern, southwestern, and eastern regions, with lowest values observed in the western and northwestern regions. 


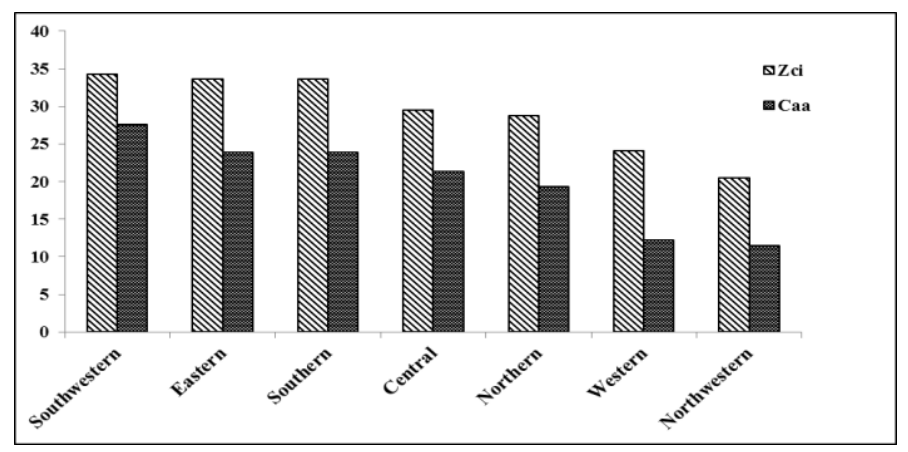

Fig. 4. Total indicator of content $\left(\mathrm{Z}_{\mathrm{ci}}=\sum \mathrm{C}_{\mathrm{c}}\right)$ and cumulative abnormality coefficient $\left(\mathrm{C}_{\mathrm{aa}}=\sum \mathrm{C}_{\mathrm{c} \geq 1}\right)$ of elements in hair of inhabitants from different regions of the Crimea peninsula. Note: $Z_{c i}=\sum C_{c}$; $\mathrm{C}_{\mathrm{aa}}=\sum \mathrm{C}_{\mathrm{c} \geq 1}$ (comments in the text).

Thus, this data show enough high variety of elemental composition of human hair for inhabitants living at different territories of the Crimean peninsula. Comparison with territories of Russian Federation and Belarus [7,8] showed both common and specific features. For instance, on most part of Russian and Crimean territories a deficiency of essential elements $(\mathrm{Zn}, \mathrm{Cu})$ in human hair is characteristic. At the same time there are significant differences in content of some essential $(\mathrm{Ca}, \mathrm{Fe})$ and, in particular, toxic and rare elements. So, there is different content of elements in human hair such as Th, $\mathrm{Ce}, \mathrm{Au}, \mathrm{U}$, $\mathrm{Ag}, \mathrm{Cs}$, which may be determined both by natural features of the Crimean territory and anthropogenic loads. It requires further investigation and more detailed data consideration.

This study was funded by the V.I. Vernadsky Crimean Federal University's Development Programme 2015-2024, within the projects entitled "Application-Based Support for the University's Staff Academic Mobility 2017" and "Academic mobility of young scientists in Russia 2017". Mercury analysis was funded by RFBR according to the research project № 18-29-24212\18 entitled "Development of neutralization of mercury-containing waste without heating and the formation of wastewater", 2018-2021 years; elemental composition in inhabitants in Sevastopol was possible due to RFBR project № 18-45-920042 entitled "Bioecological monitoring of heavy metals at board of Black Sea of Crimea", 2018-2020 years.

\section{References}

1. N.A. Dragan, Soil resources of the Crimea, Dolya Publ., Simferopol (2004)

2. A.Y. Dolgopolov, et al., Comprehensive assessment of the state of land with intensive anthropogenic impact on the natural environment, Vor. State Univ., Voronezh (1997)

3. A.A. Kist, L.I. Zhuk, Human Hair Composition at The Problems of Global Ecology, Uzbek Academy of Sciences, Tashkent (1991)

4. V.V. Kovalskij, Y.V. Kovalskij, Problems of biogeochemistry of trace elements and geochemical environment, Rosselhozakademija, Moscow (2009)

5. A.V. Bgatov, Phylosophy of Science, 2, 12-24 (1999)

6. Y.E. Saet, et al., Geochemistry of the Environment, Nedra, Moscow (1990)

7. N.V. Baranovskaya, et al., The Human Geochemistry Essay, Deltaplan, Tomsk (2015)

8. N.A. Gres, A.V. Skalny, Bioelement status of the population of Belarus: environmental, physiological and pathological aspects, Harvest, Minsk (2011) 